\title{
Fair-Value Accounting's Role in the Global Financial Crisis?: Lessons for the Future
}

\author{
Najeb Masoud ${ }^{1} \&$ Abdullah Daas ${ }^{1}$ \\ ${ }^{1}$ Determent of Accounting and Finance, Middle East University Business School, Jordan \\ Correspondence: Najeb Masoud, Determent of Accounting and Finance, Middle East University Business School, \\ Jordan, P O Box 383, Amman 11831, Jordan. Tel: 962-78-632-0186. E-mail: najeb2000@gmail.com
}

Received: August 1, $2014 \quad$ Accepted: August 25, $2014 \quad$ Online Published: September 28, 2014
$\begin{aligned} & \text { doi:10.5539/ijms.v6n5p161 } \\ & \text { URL: http://dx.doi.org/10.5539/ijms.v6n5p161 }\end{aligned}$

\begin{abstract}
This paper debates how fair-value accounting (FVA) that were deeply affected by the global financial crisis. The global financial crisis started in advanced economies spreading to emerging markets and low-income countries. Thus, it has been affected in the middle of 2007 and into 2009, which have examined the role of FVA in the financial crisis. This paper is used the value-relevance of fair-value reported under FAS 157 that estimates assets and liabilities in terms of a simple theoretical and empirical analysis literature framework. This empirical study proposed is a global crisis that not a normal cyclical crisis of capitalism. Also, it requires a change in the management policy to be tackled with new regulatory frameworks for financial institutions in order to stimulate economic activities. In other words, FVA may have amplified the crisis. Future research is needed to meet up-to-date information regarding the nature of capital markets and financial institutions. This requires a new theory of economics; for instance, a change from equilibrium theory to reflexivity theory which requires a change in the underlying model of the economic activity framework. Therefore, this study has concluded a new theory of the change of equilibrium to reflexivity that led to develop the model in the framework of the economic activity.
\end{abstract}

Keywords: global financial crisis, fair-value accounting, FAS 157, valuation, financial regulation, financial assets and liabilities

\section{Introduction}

Fair-value Accounting (FVA) is defined in IAS 39 as the price at which an asset could be exchanged in a current transaction between knowledgeable and willing parties (FASB, 2006); often also called mark-to-market accounting (MTM) is the practice of banks and other financial institutions updating the valuation of assets or securities on a regular basis. For liabilities, FVA is defined as the amount that would be paid to transfer the liability to a new debtor. Likewise, FAS 157 defines FVA as: the price that would be received to sell an asset or paid to transfer a liability in an orderly transaction between market participants at the measurement date (FASB, 2008).

Therefore, the FVA constitutes a hypothetical market price under idealised conditions (Hitz, 2005a). This definition indicates that the FVA is a market-based measure of value (Hitz, 2005b). Hence, for accounts arguing that FVA played a substantial role in deepening the financial crisis (e.g., Wallison, 2008; Whalen, 2008; Forbes, 2009). Consequently, FVA has been blamed for the latest credit crisis, being often considered as "the scapegoat" and exacerbated its severity for financial institutions in the US during 2007/2008 which quickly transformed to a Global Financial Crisis (GFC) and around the world. Eventually, the subprime mortgage crisis became a global issue, either directly due to the poor lending practices in countries such as England, Ireland, and Spain, or because of unsustainable growth in countries such as India and China.

Due to the inactivity of the markets, the key claims are that FVA contributes to excessive leverage in boom periods and leads to excessive impossible to perform a reliable market valuation. The valuation issue increased depreciation due to the posed an even greater problem. The problem with this arises when the market for an asset that a company values at fair value becomes illiquid (Penman, 2007; Benston, 2008). In addition, earlier in 2008 and mid of 2009, key FASB and other standard setters issued additional guidance regarding how to account for securities in illiquid, distressed, or disrupted markets. Others did not properly evaluate the estimates that management used to value the assets and liabilities. 
The objective of this paper is to provide a comprehensive literature review and identifying the main methodologies and research techniques that have been used of the relationship between the global financial crisis and the role of fair-value accounting. It was confirmed that the literature review plays an important role in delimiting the context of the topic or research problem in the field of social sciences. Furthermore, literature review enabled the researcher gain knowledge in the field to be the primordial method in distinguishing what has been done from what needs to be done, seeking new lines of inquiry, avoiding fruitless approaches, gaining methodological insights, identifying recommendations for further research (Gall et al., 1996), and placing the research in a historical context to show familiarity with state-of-the-art developments (Ray et al., 2002). The latest financial crisis essentially provides a unique context to gain insights into the implementation of FVA and to assess the broader consequences deriving from its adoption.

\section{An-Overview}

\subsection{Historical Background}

The birth of fair value concept in accounting theory can be traced back to the 1930 's of the $20^{\text {th }}$ century. In the late $19^{\text {th }}$ century and early $20^{\text {th }}$ century, it was introduced by the German and French legislation with the impact on accounting practice (Richard, 2005). Thus, FVA was common for firms to value their capital assets using evaluated values that the assets would bring in the market (Diewert, 2005). Therefore, many early economists also believed that the fair value accounting, known as Mark-to-Market accounting, which was first used back during the Great Depression, but it was suspended in 1938 by President Franklin D. Roosevelt (McTeer, 2009). However, during the 1930s, abusive valuation practices by various managers led to the enactment of more formal accounting standards by the accounting profession. As a result, historical cost accounting (HCA) (Note 1) emerged as the dominant practice for reporting most assets and liabilities (Chambers, 1966; Sterling, 1970). Additionally, lack of transparency under HCA could make matters worse during crises. It is generally accepted that FVA is more appropriate than HCA when the markets in which the assets are traded are highly liquid (Penman, 2011). However, HCA do not reflect the current fundamental value of an asset either. Therefore, it might be better to use market values, even if the markets are illiquid, and to supplement them with additional disclosures, e.g., about the fundamental value of the asset when held to maturity.

Although most of the debate seems to be focused on the role of FVA in the crisis, it seems equally important to ask and study to what extent HCA (e.g., for loans) may have played a role. For instance, HCA likely provides incentives to involve in so-called "gains trading" or to securitise and sell assets. However, it is important to recognise that a bank can also increase its leverage in boom periods under HCA by selling an asset, as banks did when they securitised loans. Moreover, there is evidence suggesting that banks' loan losses exceeded fair-value losses on securities (e.g., Merrill, 2008; Lim et al., 2011). We can argue that over time, HCA becomes less and less thoughtful to what the market think about specially instruments, and it doesn't produce the kinds of signals that investors are interested in.

\subsection{Measures of Fair-Value Accounting}

FVA is a way to measure financial assets and liabilities have to be recognised at amortised cost under the accounting rules. The FVA rules are contained in IAS 39 for banks that apply International Accounting Standards. In 2003, the IASB modified IAS 39 to add an option to use fair value through income for subsequent measurement of any asset or liability in order to correct an accounting mismatch. Besides the increase in the cost of capital, fair values may also become less reliable during the crisis (Ryan, 2008). The reclassification amendment to IAS 39 may have contributed to the reduced value relevance of fair values.

The way in which standards require FVA to be measured is still evolving. The FVA rules in U.S. generally accepted accounting principles (GAAP) are FAS 157 released its Financial Accounting Standards that provides a fair value measurement framework. To make these measurements market-based, FAS 157 recognise three levels of fair value (FASB, 2008): Level 1, Level 2, or Level 3. Level 1 is the current price in a liquid market for exactly the same instrument. Level 2 is the current price in a liquid market for a similar instrument, which can be adjusted to obtain the fair value of the instrument being valued. Level 3 assets do not have observable inputs, and therefore, inputs and is commonly referred as "market-to-model" because it is often the outcome of a mathematical modelling implementation with various assumptions about economic, market or firm-specific conditions. Consequently, FAS 157 applies when other Financial Accounting Standards Board (FASB) statements refer to the use of fair value or for assets/ liabilities to be recorded at fair value, but prior to the declaration of FAS 157, no clear method had been outlined among the many FASB statements and limited guidance for applying the standards in compliance with GAAP.

However, the benefits from increased consistency and comparability in FVA measurements and expanded 
disclosures about those measurements should be on-going. In particular they would argue that FVA provide two types of information: information about the banks' ability to make profits from speculative activities and information about bank risk. Indeed, little literature shows that FVA gains and losses provide incremental information to analysts and investors on bank risks (Hodder et al., 2006; Blankespoor et al., 2012). As noted previous, FVA as required by US GAAP or IFRS as well as U.S. regulatory capital requirements for banks have mechanisms in place that should alleviate potential contagion effects.

\subsection{Boom and Collapse of the Shadow Banking System}

Banks are governed by tight regulations designed to ensure the stability of the financial system and to protect investors (Turner, 2010). The banks are also required to set aside a minimum amount of their assets as liquid assets in the reserve requirements, which vary across countries (BIS, 2006). However, there is strong evidence that the riskiest, worst performing mortgages were funded through the "shadow banking system" and that competition from the shadow banking system may have pressured more traditional institutions to lower their own underwriting standards and originate riskier loans (Simkovic, 2011). Krugman (2011), described the run on the shadow banking system as the "core of what happened" to cause the crisis. He referred to this lack of controls as "malign neglect" and argued that regulation should have been imposed on all banking-like activity.

Banks are heavily scrutinised by the regulators, given the significant amount of regulatory reports banks have to prepare. The regulators have the power to order reorganisation and to remove bank management and directors if a bank has accounting irregularities and runs into financial difficulties (Barth et al., 2001). The securitisation markets also remain impaired, as investors anticipate more loan losses. Investors are also uncertain about coming legal and accounting rule changes and regulatory reforms (Zandi, 2011). The banking sector in the US reported billions of dollars of impairment losses on the FVA of its assets and liabilities as "goodwill" on its balance sheets (Ramanna and Watts, 2009), this "goodwill" is regularly tested for impairment and needs to be written down if the FVA of "goodwill" is below its book value. Further evidence on banks' reluctance to recognise losses comes from a goodwill impairment study by Disclosure Insight (2009), an independent investment research firm. We can argue that, when the banks are more risky by using financial instruments that require more subjective FVA, the FVA may still remain value relevant. It is thus an empirical matter to consider whether the value relevance of FVA increases with bank risk or with the carrying value of the loans.

\subsection{Fair-Value Accounting and Financial Crises}

To improve the profitability of banks, mortgage loans were securitised using so-called special purpose vehicles and sold on capital market. The framework for measuring FVA builds on current practice and requirements. However, Late 2001 through early 2008 period was one of considerable economic prosperity for the U.S., then a significant contributor to that prosperity was wealth (or economic activity) generated through poor lending practices and loose regulatory oversight. Basically, accounting standards could not afford, and enabled financial institutions to record inflated revenues related to these home loans without recourse from auditors and analysts. However, the Federal Reserve Board began to increase interest rates from the low (4 percent) prime rates during period from 2002 to 2004 to over (5 percent) in early 2005, increasing up to ( 8.25 percent) in 2007 . Thus, encourage the crisis soon spread to investors in the financial sector had tremendous follow-on effects. The argument is that FVA and asset values allow banks to increase their leverage in booms, which in turn makes the financial system more vulnerable and financial crises more severe (Persaud, 2008; Plantin et al., 2008).

Therefore, the historical experience of the U.S. was that in 1929, after the crash, they accused accountants of putting water on the balance sheet in the 1920s. In October 2007, the market (using the Dow Jones Industrial as a benchmark) dropped precipitously from over 14,000 to under 7,000 in March 2009, with a drop of almost 2,000 points in one week alone in late September 2008. Fearing a recession, Americans began to consume less. Companies started lying off workers in large numbers, which further reduced consumption. Job losses began to mount as almost every industry was affected; the U.S. experienced the most dramatic rise in unemployment from (4.6 percent) in 2007 to (9.3 percent) in 2009 (SEC, 2010). Allen and Carletti (2008) and others argue that FVA would have helped to identify the problems leading to the savings and loan crisis earlier.

In response to these concerns, the accounting community has spread in two: the ones that blame FVA and consider it for been a factor that causes the financial crisis and the ones that praise FVA. Although the institutional framework takes an economics approach, it seeks to introduce into the analysis the social, political and cultural dimensions.

\subsection{Did Fair-Value Accounting Contribute to the Crisis?}

Based on early analysis and the evidence in the previous discussion, we have little reason to believe that FVA 
contributed to the financial crisis in a major way. Much debate has focused on this issue. One issue is that FVA loses many of its desirable properties (Note 2) when prices from active markets are no longer available and hence models have to be used, which in turn makes it very difficult to determine and verify fair values. Thus, it is certainly possible that FVA rules and the details of their implementation could be further improved. William Isaac in October 2008, the former FDIC chairman is quoted as saying that, "I got to tell you that I can't come up with any other answer than that the accounting system is destroying too much capital, and therefore diminishing bank lending capacity by some $5 \$$ trillion. [...] It's due to the accounting system, and I can't come up with any other explanation" (Katz, 2008). On its own, FVA play only a limited role for banks' income statements and regulatory capital ratios, except for that a few banks with large trading situations. This implies that the case for loosening the existing FVA rules is weak (SEC, 2008).

It appears from the discussion so far that FVA reporting is essentially reflecting the decisions that were made by managers, by boards, and, to some degree, by independent accountants who opined on the financial statement. To determine the amount of the gain, as well as the corresponding effects of the transaction on the balance sheet, management must determine the fair value of the related assets. The balance sheet gives you the fair value but it doesn't give you the FVA "at risk" connected with some of these more exotic instruments (Penman, 2011). Finnegan (2012) argued that the fact that fair value can be difficult to determine in the absence of readily available market prices is not a reason to abandon the approach.

Based on the discussion above, it seems that there is two inclusive clarifications provide the role of FVA in the financial crisis and are consistent in their conclusions with the findings reported by the Securities and Exchange Commission (SEC) in December 2008. In this context, Ryan (2008) states that VFA didn't contribute to the crisis because it provided investors with needed accurate and complete information concerning subprime positions. He explained that, there is a need for additional guidance as to what is an orderly transaction, due to the use of inputs for VFA is driven by conditions at the measurement date. Similarly, in the context of FVA in the financial crisis, Laux and Leuz (2009) observed that FVA probably didn't contribute to the crisis to such a large extent but was also not merely a messenger. They argued that, the FVA debate is a new version of the relevance versus reliability argument. Furthermore, there are legitimate concerns about marking asset values to market prices in times of financial crises because they are tied to various contracts and capital ratio for banks regulations.

The preceding sections illustrate that the debate about FVA is full of arguments that do not hold up to further scrutiny and need more economic analysis. We need to make more progress on the question of whether FVA did in fact contribute to the financial crisis through contagion effects. At present, there is little research that would answer or even directly speak to this question.

\section{Theoretical Framework Considerations}

The key theoretical argument for FVA is that fair values are value-relevant. FVA was chosen as a preferred solution in a never-ending trade-off between reliability and relevance of accounting information (Barth, 2006). FVA also was originally adopted because assets and liabilities measured using FVA is more relevant for decision making and financial reports based on HCA is irrelevant when the assets FVA exceeds the HCA (Foster and Shastri, 2010). Laux (2012) further argue that even if FVA can be manipulated, they are still value-relevant potentially more useful than HCA. Thus it is not possible to provide a clear theoretical prediction of the effect of the crisis on the receptiveness of bank stock returns to FVA gains and losses. FVA is also cited for bringing price bubbles into financial statements (Penman, 2007), leading financial institutions to react to market changes in the way that they would not normally act (Foster \& Shastri, 2010) and this recognition could lead to a flight to quality, thereby depressing stock prices (Francis et al., 2012). In other words, the FVA estimates would fully reflect the consensus expectation of the investors, eliminating concerns over errors in measurement (Hitz, 2007; Barth \& Landsman, 2010).

Studies from other early researcher, for instance Barth (1994) found that the disclosed FVA of investment securities and securities gains and losses are reflected in stock prices. In contrast, Barth et al. (1996) reported that loans' FVA have increment al explanatory power on stock prices when conditioned on non-performing loans and interest sensitive assets and liabilities. On the other hand, there are several important opinions in favour of FVA. However, ABA (2008), MBA (2008), and U.S. (2008) argued that FVA was worsening the crisis by creating a downward spiral and that observed market prices were significantly below the assets' fundamental values. Despite the argument regarding the strongest opposition against FVA perhaps comes from Wallison (2008) who debates that FVA has been the principal cause of an unprecedented decline in asset values; an unprecedented rise in instability among financial institutions; and the worst economic crisis in the U.S. since the Great Depression (Khan, 2010). 
For derivatives, Venkatachalam (1996) finds that the disclosed FVA use of derivatives have additional explanatory power for stock prices over the notional derivative amounts. For instance, Macintosh et al. (2000) argue that the market uses accounting earnings, along with other information, to value firms' stock and other securities. However, the prices of many of these securities underlie derivatives' prices, which then find their way into financial statements through FVA. Prior studies provide evidence that the FVA of securities, derivatives and loans are value relevant (Barth, 1994; Barth et al., 1996; Venkatachalam, 1996). In response to these concerns, the rapid occurrence of financial derivatives and asset securitisation joined with their weak regulation could be the second factor causing the crisis.

It appears from the discussion so far that FVA measurement should not be blamed for the economic downturn and financial crisis; the root of problems is lying outside this part of financial reporting. On the contrary, the recent financial crisis helps us to reveal that FVA can be a significant tool to distinguish healthy companies from unhealthy ones. The failure of some banks could have increased market illiquidity, which in turn may have spilled over to other banks via FVA; thereby creating an endogenous risk, while we can argue in different way that illiquidity leads to asset prices being a function of liquidity available in the market.

\section{Empirical Analyses: The Evidence}

In the previous section the relevant theoretical literature on FVA diffusion in financial crisis was discussed. In this section, an overview of the findings of empirical studies relating to the issues associated with FVA can reduce their value relevance. The value relevance of FVA can vary across different classes of assets are provided. The empirical evidence illustrations that for level 3 assets, which are illiquid financial instruments and opaque, the costs of capital and bid-ask spreads are higher than that of levels 1 and 2 assets (Riedl \& Serafeim, 2011). This is based on the theory that the uncertainty in valuation estimates increases across levels 1 to 3 assets. This valuation uncertainty leads to systematic risks, which in turn results in higher costs of capital measured by equity betas for the level 3 assets relative to levels 1 and 2 assets. In addition, the increasing information asymmetry across levels 1 to 3 assets also causes the bid-ask spreads to correspondingly increase (Note 3). Banz (1981), and Reinganum \& Smith (1983) indicate that information risk should be diversifiable in an economy. Bleck and Liu (2007) use an analytical model to display that FVA provides greater transparency on the underlying asset values and serves as an early warning sign on the firm's financial health. Their model shows that HCA can cause the financial markets to be more, as opposed to less volatile.

Particular researchers Kolev (2008), Goh et al. (2009), and Song et al. (2010) investigate the market pricing of banks' FVA assets as implied by their share prices relative to other assets and across FVA input categories. Though, the point estimates differ across studies "due to different samples and specifications", there is diminutive evidence that market valuations of the FVA assets in 2008 exceeded their reported values, which might indicate excessive write-downs. Kolev (2008) examine the value-relevance of the three levels of assets reported under FVA provided by FAS 157, based on audit committee financial expertise in the first two quarters of 2008. His sample comprises includes in the first quarter of banks (88), financial services firms (35), and insurance companies (54); and in the second quarter of banks (86), financial services firms (34), and insurance companies (52). His basic framework model regression is as follows:

$$
P_{i t}=\beta_{0}+\beta_{1} \text { NetEB } V_{i t}+\beta_{2} \text { Leve } 1+\beta_{3} \text { Leve } 2+\beta_{4} \text { Leve } 3+\sum \beta_{i} \text { contols }+\varepsilon_{i}
$$

where $P_{i t}$ price per share of common stock (dependent variable); $i$ indicates a given firm; $t$ indicates a given quarter; and fair-value is defined in terms of net assets (Level 1,2 and 3); NetEBV is the difference between book value of equity and net assets reported at fair value.

Kolev (2008)'s empirical analysis found that, coefficients on historical cost book value of equity between 0.709 and 0.748 in the first quarter (Q1), while investors perceive reported values under all three levels net assets to be

value-relevant, with minor differences between $\beta_{2}(0.811), \beta_{3}(0.772)$, and $\beta_{4}(0.709)$ (see Kolev's Table 4,

Panel A). These findings confirm on the mark-to-market that one dollar of level 1 net assets is valued at 0.811 US \$ by stock market investors. The valuation coefficient, however, decline between quarters, Q1 and Q2, reflecting greater uncertainty about underlying asset values, therefore all levels of FVA net assets it was sell at significantly less than their book value. Furthermore, there was a valuation of mark-to-model net assets gap

between the valuation of level 1 net assets $\left(\beta_{2}=0.604\right)$, level 2 net assets $\left(\beta_{3}=0.582\right)$, and level 3 net assets 
( $\beta_{4}=0.419$ ), the latter being valued at a significant discount by investors. Also, the study revealed that valuations of FVA are lower for firms with lower equity capital and firms that develop their mark-to-model internally. Therefore, the extent of the valuation of mark-to-model net assets gap is reduced if the expertise of audit committee members is enhanced.

At the same time, Goh et al. (2009) conducted a sample comprises of 516 U.S. banks a similar examination for the first three quarters of 2008 to Kolev's but includes a more inclusive set of control variables. Their findings revealed that, in the first quarter (Q1), while investors perceive reported values under all three levels net assets to be value-relevant, with minor differences between $\beta_{2}(0.743), \beta_{3}(0.650)$, and $\beta_{4}(0.583)$ (see Goh et al., 2009: Table 8, Panel B). These findings confirm difference in pricing between mark-to-market and mark-to-model assets that one dollar of level 1 net assets is valued at 0.743US \$ by stock market investors, a significant discount to book value. The valuation coefficient of FAV assets, however, it was a significant shift by the Q2. Therefore, there was a valuation of mark-to-market and mark-to-model of level 1 net assets was matched their book value ( $\beta_{2}=1.086$ ), a significantly increase from $\mathrm{Q} 1$ to the $\mathrm{Q} 3$. Furthermore, investors significantly demote the valuation of level 3 net assets $\left(\beta_{4}=0.296\right.$ ), which was valued at a deep discount to their book value. The valuation of level 2 assets remains more or less the same between Q1 and Q3. The result doesn't change much in the Q3, with level 1 net assets still being valued at close to book value $\left(\beta_{2}=1.153\right)$, level 2 net assets ( $\left.\beta_{3}=0.512\right)$, and level 3 net assets $\left(\beta_{4}=0.254\right)$, while remain valued at a discount. Finding evidence that investors value Level 2 net assets less than Level 1 net assets but do not value Level 2 and Level 3 net assets differently. Specifically, the extent of a higher capital ratio and a higher-quality do allow a bank to enhance the value-relevance of it is level 2 and level 3 net assets close to their book values. Goh et al. (2009) also document that the value relevance of net fair value assets decreases over the first three quarters of 2008 during an economic crisis.

Another important distinction found in the empirical study by Song et al. (2010) examines the value-relevance of fair value estimates of assets and liabilities across the three categories under the FAS 157 hierarchy. Using a sample of 431 banking that disclosed FAS 157 early adopters in 2008. In contrast to Kolev (2008) and Goh et al. (2009), they don't report distinct valuation figures by quarters and don't combine fair value assets and liabilities together for regression purposes. Their basic framework model regression is as follows:

$$
\begin{aligned}
& P_{i t}=\beta_{0}+\beta_{1} \text { NetEB } V_{i t}+\beta_{2} \text { Leve } 1 A+\beta_{3} \text { Leve } 2 A+\beta_{4} \text { Leve } 3 A+ \\
& \beta_{5} \text { Leve } 1 L+\beta_{6} \text { Leve } 2 L+\beta_{7} \text { Leve } 3 L+\sum \beta_{i} \text { contols }+\varepsilon_{i}
\end{aligned}
$$

where $P_{i t}$ price per share of common stock (dependent variable); $i$ indicates a given firm; $t$ indicates a given quarter; and fair value is defined in terms of net assets (Level $1 \mathrm{~A}$, Level 2 A and Level $3 \mathrm{~A}$ ); while liabilities is defined as Level $1 \mathrm{~L}$, Level $2 \mathrm{~L}$ and Level $3 \mathrm{~L}$ ); NetEBV is the partition book value into non-fair value $(N F V A)$ assets and liabilities and each of the FVA levels. Song et al. (2010) reported that, on average, level 1 ( $\left.\beta_{2}=0.968\right)$ and level 2 assets $\left(\beta_{3}=0.972\right.$ ) are not significantly different from one or negative one, which 
valued by investors at close to their reported book (i.e., fair market) values (see Song et al., 2010, Table 3).

Coefficient for value-relevant, level 3 assets are priced at a significant discount is less than one $\left(\beta_{4}=0.683\right)$ and

significant at the 0.01 level. Furthermore, both coefficient on level $1\left(\beta_{5}=-0.818\right)$ and $2\left(\beta_{6}=-1.006\right)$ liabilities are significant at the 0.01 level, and also valued at close to their book (i.e., market) values. In such coefficient on level 3 liabilities are priced at double their reported fair market values which less than negative one $\left(\beta_{7}=-2.185\right)$ and significant at the 0.01 level, thus implying that investors severely double the reliability of FVA-based liabilities. They further observed that, the value-relevance of fair values especially Level 3 fair values assets and liabilities are greater for firms with strong corporate governance. Governance measures encompasses: board independence, audit committee activity, ownership, audit size, and internal controls.

The key conclusion to draw from these findings is that, under crisis conditions (i.e., second or third quarter of 2008), it appears that investors revise the value relevance decreases for the level 3 assets, consistent with higher information asymmetry and lower reliability for level 3 assets compared to levels 1 and 2 assets due to increase uncertainty and potentially more managerial discretion underlying their measurement. Interestingly, they find that Level 3 fair values are associated with price only in specific circumstances.

In other words, the evolution in the valuation of level 1 assets is more difficult to pin down, with Kolev (2008) reporting a fall in their valuation and Goh et al. (2009) being more comprehensive as well as different empirical models, which document that the value relevance of net fair value assets decreases over the first three quarters of 2008, whereas Song et al. (2010) find that the value relevance of fair values does not decrease over this period. Further work we suggested that, in order to examine the value-relevance of FVA's role in the financial crisis is needed to reconcile both sets of findings.

\section{Findings}

\subsection{Regression Results}

The results of the regression analysis reported by (Kolev, 2008; Goh et al., 2009; Song et al., 2010). Song et al. (2010) indicates that the valuations of Level 1 and Level 2 assets and liabilities close to one and negative one, these papers find valuations of Level 1 and Level 2 net assets significantly less than one. Kolev (2009) uses a changes specification, allowing tests of the value relevance of Level 3 realised and unrealised gains/losses versus net purchases and transfers. Goh et al. (2009) document that investors value Level 2 net assets less than Level 1 net assets but do not value Level 2 and Level 3 net assets differently. In contrast, Song et al. (2010) illustrate that Level 1 and Level 2 assets are valued similarly, while Level 3 assets are valued the least. Goh et al. (2009) findings also reveal that the value relevance of net fair value assets decreases over the first three quarters of 2008, whereas Song et al. (2010) find that the value relevance of fair values does not decrease over this period. Furthermore, Song et al. (2010) Find evidence that the value relevance of fair values does not decrease as markets become less liquid may be particularly important to standard setters who are interested in the market's perception of the reliability of fair values during an economic crisis.

More importantly, the findings also indicate that all three studies find that investors priced a reported 1US\$ of Level 3 assets significantly below a reported IUS\$ of Level 1 assets. The discount relative to Level 1 assets ranges between ( 20 and 30 percent). The findings also reveal the three studies show that the relative discount of Level 3 assets is smaller when the reported values are likely to be more credible, that is, for firms using Big Four auditors, external valuations, having several financial experts on the audit committee, and for firms with independent board members and strong internal controls.

\subsection{Contribution of FVA}

In addition to the aforementioned prior results findings and on available data, the following indicators give a strong insight into the state of the contribution of FVA to financial crisis. Overall, finding suggest that (1) FVA-derived information is value-relevant under FAS 157 in 2008, consistent with extensive prior research; (2) investors perceive level 3 assets and liabilities FAS values to be measured less reliability with price less than (100 percent) significantly; (3) strong governance and capital ratios enhance confidence in reported statistics; and (4) investors were significantly discounting factors to the reported level 3 FVA because they stem from 
valuation models with (unobservable, inputs) values, and consistent with more model risk (or noise) and large information asymmetry. The implicit prices assigned by investors' valuation of the fair value to level 1 assets (observable, inputs) values, rose over the year, suggesting that investors perceived market prices to be depressed.

\section{Conclusion}

Apart from further analysing the findings presented and discussed, this part has considered some significant outcomes of the potential role of FVA during the financial crisis. In the light of various contributions based on prior analysis and the evidence reviewed earlier from the literature. There is reason to believe that FVA is more than just a messenger may have contributed to the acceleration of the bad news in the financial crisis in a major way. FVA play only a limited role for banks' income statements and regulatory capital ratios, except for a few banks with large trading positions. The failure of some banks could have spilled over to other banks via FVA.

During the financial crisis, unemployment rates have risen, prices for mortgage related securities fell significantly and markets for them became illiquid. The result was banks marking down their assets by significant amounts and money has been lost from what were thought to be good investments. FVA allows for certain assets to be valued at the amount for which they could be exchanged in an open market transaction. The problem with this arises when the market for an asset that a company values at fair value becomes illiquid. While most of the debate seems to be focused on the role of FVA in the crisis, it seems equally important to ask and study to what extent HCA (i.e., for loans) may have played a role. The result further validated the argument that the debate about FVA don't hold up to further enquiry and need further economic analysis. Although, the regression analyses model examined were used to test the FVA did not cause the financial crisis; it may have worsened the negative effects. Instead, FVA is a necessary part of the economic recovery, and through revision of current standards, mark-to-market will prove to be a valuable tool in the prevention of similar crises. Furthermore, lack of full disclosure by management in their financial reporting is more to blame for the crisis.

Further research is needed in order to provide a clear understanding of the framework that managers face under current regulatory rules in the banking system and financial markets in general. There is also a need to identify remedies for the developing regulatory framework in order to improve current practices. As a result of the crisis, regulation is rising and is creating new challenges that need managing. One may surmise that current accounting standards, such as those relating to FVA, overstretch accountants' current capabilities and prior learning and obscure other informational needs by investors and other interested stakeholders.

\section{References}

ABA American Bankers Association. (2008). Letter to Robert H. Herz, Chairman, Financial Accounting Standards Board. Retrieved from http:/www.aba.com/NR/rdonlyres/DC65CE12-B1C7-11D4-AB4A-00508B95258D/56797/ABAlettertoFA SBOTTINovember132008.pdf

Allen, F., \& Carletti, E. (2008). Mark-to-market accounting and liquidity pricing. Journal of Accounting and Economics, 45(2/3), 358-378. http://dx.doi.org/10.1016/j.jacceco.2007.02.005

Banz, R. W. (1981). The relationship between return and market value of common stocks. Journal of Financial Economics, 9, 3-18. http://dx.doi.org/10.1016/0304-405X(81)90018-0

Barberis, N., \& Thaler, R. (2003). A survey of behavioral finance. In G. M. Constantinides, M. Harris., \& R. M. Stulz (Eds.), Handbook of the economics of finance (Vol. 1, pp. 1053-1128). North Holland, Amsterdam: Elsevier.

Barth, M. E. (1994). Fair value accounting: Evidence from investment securities and the market valuation of banks. The Accounting Review, 69(1), 1-25.

Barth, M. E. (2006). Including estimates of the future in today's financial statements. Accounting Horizons, 20(3), 271-285.

Barth, M. E., \& Landsman, W. R. (2010). How did financial reporting contribute to the financial crisis? European Accounting Review, 19(3), 399-423. http://dx.doi.org/10.1080/09638180.2010.498619

Barth, M. E., Beaver, W. H., \& Landsman, W. R. (1996). Value-relevance of banks' fair value disclosures under SFAS No. 107. The Accounting Review, 71(4), 513-537.

Barth, M. E., Beaver, W. H., \& Landsman, W. R. (2001). The relevance of the value relevance literature for financial accounting standard setting: Another view. Journal of Accounting and Economics, 31(1-3), 77-104. http://dx.doi.org/10.1016/S0165-4101(01)00019-2 
Benston, G. J. (2008). The shortcomings of fair-value accounting described in SFAS157. Journal of Accounting and Public Policy, 27(2), 101-114. http://dx.doi.org/10.1016/j.jaccpubpol.2008.01.001

BIS. (2006). Basel II: International Convergence of Capital Measurement and Capital Standards. Bank for International Settlements, Basel Switzerland. Retrieved from http://www.bis.org/publ/bcbs128.pdf

Blankespoor, E., Linsmeier, T. J., Petroni, K., \& Shakespeare, C. (2012). Fair value accounting for financial instruments: Does it improve the association between bank leverage and credit risk? The Accounting Review, 88(4), 1143-1177. http://dx.doi.org/10.2139/ssrn.1565653

Bleck, A., \& Liu, X. (2007). Market transparency and the accounting regime. Journal of Accounting Research, 45(2), 229-256. http://dx.doi.org/10.1111/j.1475-679X.2007.00231.x

Chambers, R. J. (1966). Accounting, evaluation and economic behavior. Houston: Scholars Book.

Diewert, W. E. (2005). Issues in the measurement of capital services, depreciation, asset price changes, and interest rates. In G. Gorrado, J. Haltiwanger, \& D. Sichel (Eds.), Measuring Capital in the New Economy (pp. 479-542). Ghicago: University of Ghicago Press.

Disclosure Insight. (2009). Bank goodwill impairment study. Retrieved from https://www.sec.gov/comments/4-573/4573-230.pdf

Evans, M., Frech, N., \& O'Roarty, B. (2001). Accountancy and corporate property management. Journal of Property Investment and Finance, 19(12), 211-223. http://dx.doi.org/10.1108/14635780110384171

FASB Financial Accounting Standards Board. (2006). Statement of financial accounting standards No. 157. Fair Value Measurements. FASB, Stamford, CT.

FASB Financial Accounting Standards Board. (2008). Determining the fair value of a financial asset when the market for that asset is not active. FASB Staff Position, FSP FAS, pp. 157-3, October 10. Retrieved from http://www.fasb.org/pdf/fsp_fas157-3.pdf

Finnegan, P. (2012). IFRS9-Limited amendments, significant improvements. Retrieved from http://www.ifrs.org/Investor-resources/2012-perspectives/December-perspectives/Documents/Patrick-Finne gan-IFRS-9-Limited-Amendments-Significant-Improvements.pdf

Forbes, S. (2009). Steve: End mark-to-market. Forbes Magazine, March 23. Retrieved from http://www.forbes.com/fdc/welcome_mjx.shtml

Foster, P. B., \& Shastri, T. (2010). The subprime lending crisis and reliable reporting. Accounting and Auditing, CPA Journal, 80(4), 22-25.

Francis, B., Hasan, I., \& Wu, Q. (2012). Do corporate boards matter during the current financial crisis? Review of Financial Economics, 21(2), 39-52. http://dx.doi.org/10.1016/j.rfe.2012.03.001

Gall, M. D., Borg, W. R., \& Gall, J. P. (1996). Educational research (6th ed.). White Plains, NY: Longman Publishers USA.

Goh, B. W., Ng, J., \& Yong, K. O. (2009). Market pricing of banks' fair value assets reported under SFAS 157 during the 2008 economic crisis. Working Paper, Massachusetts Institute of Technology and Singapore Management University. Retrieved from http://www.capana.net/download/2009papers/Beng\%20Wee\%20Goh.pdf

Hitz, J. M. (2005a). Fair value in der IFRS-Rechnungslegung- Konzeption, Inhalt und Zweckmßäigkeit. Die Wirtschaftsprüfung, 58(18), 1013-1027.

Hitz, J. M. (2005b). Rechnungslegung zum fair value: Konzeption und Entscheidungsnützlichkeit. Frankfurt: Peter Lang.

Hitz, J. M. (2007). The decision usefulness of fair value accounting-A theoretical perspective. European Accounting Review, 16(2), 323-362. http://dx.doi.org/10.1080/09638180701390974

Hodder, L. D., Hopkins, P. E., \& Wahlen, J. M. (2006). Risk-relevance of fair value income measures for commercial banks. The Accounting Review, 81(2), 337-375. http://dx.doi.org/10.1108/20421161111107831

Katz, D. M. (2008). Former FDIC Chief: Fair Value Caused the Crisis. Accounting and Tax. Retrieved from http://ww2.cfo.com/accounting-tax/2008/10/former-fdic-chief-fair-value-caused-the-crisis/

Khan, U. (2010). Does fair value accounting contribute to systemic risk in the banking industry? http://dx.doi.org/10.2139/ssrn.1327596 
Kolev, K. (2008). Do investors perceive marking-to-model as marking-as-myth? Early evidence from FAS 157 disclosure. http://dx.doi.org/10.2139/ssrn.1336368

Krugman, P. R. (2009). The return of depression economics and the crisis of 2008. New York: W.W. Norton Company Limited.

Laux, C. (2012). Financial instruments, financial reporting, and financial stability. Accounting and Business Research. http://dx.doi.org/10.2139/ssrn.1991825

Laux, C., \& Leuz, C. (2009). The crisis of fair-value accounting: Making sense of the recent debate. Accounting, Organizations and Society, 34(6-7), 826-834. http://dx.doi.org/10.1016/j.aos.2009.04.003

Lim, C. Y., Lee, E., Kausar, A., \& Walker, M. (2011). Bank risk and the value relevance of fir value gains/losses. Research Collection School of Accountancy, pp. 1-42. Retrieved from http://ink.library.smu.edu.sg/soa_research/908

MBA Mortgage Bankers Association. (2008). Letter to the SEC. November 13. Retrieved from http://www.mortgagebankers.org

McTeer, R. (2009). Mark-to-market accounting: Shooting ourselves in the foot. National Center for Policy Analysis. March 24. http://www.ncpa.org/pub/ba648

Merrill, L. (2008). Industry overview, does TARP point to suspension of mark-to-market? Research Report, October 24.

Penman, S. (2007). Financial reporting quality: Is fair value a plus or a minus? Accounting and Business Research, 37(1), 33-44. http://dx.doi.org/10.1080/00014788.2014.901164

Penman, S. (2011). Accounting For Value. New York: Columbia University Press.

Plantin, G., Sapra, H., \& Shin, H.S. (2008). Marking-to-market: Panacea or Pandora's Box? Journal of Accounting Research, 46(2), 435-460. http://dx.doi.org/10.1111/j.1475-679X.2008.00281.x

Ramanna, K. (2008). The implications of unverifiable fair-value accounting: Evidence from the political economy of goodwill accounting. Journal of Accounting and Economics, 45(2-3), 253-281. http://dx.doi.org/10.1016/j.jacceco.2007.11.006

Ramanna, K., \& Watts, R.L. (2009). Evidence from goodwill non-impairments on the effects of using unverifiable estimates in financial reporting. Cambridge, Mass: Harvard Business School.

Ray, B., Scapens, R., \& Theobald, M. (2002). Research method \& methodology in finance \& accounting. London: Thomson.

Reinganum, M., \& Smith, J. (1983). Investor preference for large firms: New evidence of economies of size. Journal of Industrial Economics, 32(1), 213- 227.

Richard, J. (2005). The concept of fair value in French and German accounting regulations from 1673 to 1914 and its consequences for the interpretation of the stages of development of capitalist accounting. Critical Perspectives on Accounting, 16(6), 825-850. http://dx.doi.org/10.1016/j.cpa.2003.06.008

Ryan, S. G. (2008). Accounting in and for the subprime crisis. The Accounting Review, 83(6), 1605-1638. http://dx.doi.org/10.2308/accr.2008.83.6.1605

SEC U.S. Securities and Exchange Commission. (2008). Report and recommendations pursuant to Section 133 of the Emergency Economic Stabilization Act of 2008: Study on mark-to-market accounting. Office off the Chief Accountant Division of Corporation Finance. Retrieved from http://www.sec.gov/news/studies/2008/marktomarket123008.pdf

SEC U.S. Securities and Exchange Commission. (2010). Former countrywide CEO Angelo Mozilo to pay SEC's largest ever financial penalty against a public company's senior executive. Retrieved from http://www.sec.gov/news/press/2010/2010-197.htm

Shleifer, A. (2000). Inefficient markets: An introduction to behavioral finance. Oxford University Press.

Simkovic, M. (2011). Competition and crisis in mortgage securitization. Indiana Law Journal, 88, 213-271.

Song, C. J. (2008). An evaluation of FAS 159 fair value option: Evidence from the banking industry. http://dx.doi.org/10.2139/ssrn.1279502

Song, C. J., Thomas, W. B., \& Yi, H. (2010). Value relevance of FAS No. 157 fair value hierarchy information and the impact of corporate governance mechanisms. The Accounting Review, 85(4), 1375-1410. 
http://dx.doi.org/10.2308/accr.2010.85.4.1375

Sterling, R. R. (1970). Theory of the measurement of enterprise income. Lawrence, KS: University Press.

Turner, A. (2010). Banks are different: should accounting reflect that fact?. Speech given to the Institute of Chartered Accountants in England and Wales (ICAEW), London, UK, January 21. Retrieved from http://www.fsa.gov.uk/pages and library/Communication/Speeches/

Venkatachalam, M. (1996). Value-relevance of banks' derivatives disclosures. Journal of Accounting and Economics, 22 (1-3), 327-55. http://dx.doi.org/10.1016/S0165-4101(96)00433-8

Wallison, P. J. (2008). Fair value accounting: A critique. American Enterprise Institute for Public Policy $\begin{array}{lllll}\text { Research Outlook } & \text { Series, } & 1-8 . & \text { Retrieved }\end{array}$ http://www.aei.org/files/2008/07/28/20080728_23336JulyFSOg.pdf

Whalen, R. C. (2008). The subprime crisis-causes, effect and consequences. Networks Financial Institute Policy Brief No. 2008-PB-04. http://dx.doi.org/10.2139/ssrn.1113888

Zandi, M. (2011). The economic impact of a $\$ 750$ billion fiscal stimulus package. Retrieved from http://www.ifrs.org/Investor-resources/2012-perspectives/December-perspectives/Pages/Patrick-Finnegan-I FRS-9-December-2012.aspx

\section{Notes}

Note 1 . We prefer to call it "historical transaction analysis". There are transaction costs and limits to arbitrage, and market prices may be subject to behavioural biases and investor irrationality (e.g., Shleifer, 2000; Barberis \& Thaler, 2003).

Note 2. Property is an unusual asset as its market value can rise and fall in accordance with market conditions (Evans et al., 2001).

Note 3. For instance, concurrent research provides descriptive evidence that level 1 assets include excessively more investment securities "which tend to be more liquid", while level 3 assets include more loans "which tend to be less liquid" (Song, 2008).

\section{Copyrights}

Copyright for this article is retained by the author(s), with first publication rights granted to the journal.

This is an open-access article distributed under the terms and conditions of the Creative Commons Attribution license (http://creativecommons.org/licenses/by/3.0/). 